City, Class and Power 


\title{
City, Class and Power
}

\author{
MANUEL CASTELLS
}

Translation supervised by Elizabeth Lebas

Macmillan Education 
ISBN 978-0-333-22555-4 ISBN 978-1-349-27923-4 (eBook)

DOI 10.1007/978-1-349-27923-4

(C) Manuel Castells 1972, 1975, 1976, 1977, 1978

English translation (C) The Macmillan Press Ltd 1978

All rights reserved. For information, write:

St. Martin's Press, Inc., 175 Fifth Avenue, New York, N.Y. 10010

Library of Congress Catalog Card Number 78-2978

ISBN 978-0-312-13991-9

First published in the United States of America in 1978

Paperback reprint 1982

Library of Congress Cataloging in Publication Data

Castells, Manuel.

City, class and power.

Essays which originally appeared in French journals.

Includes bibliographical references and index.

1. City planning-Addresses, essays, lectures. 2. Social classesAddresses, essays, lectures. 3. Power (Social sciences)-Addresses, essays, lectures.

I Title

HT166.C33 309.2'62 78-2978

ISBN 978-0-312-13991-9 


\section{Contents}

Acknowledgements vii

I Urban Crisis, Political Process and Urban Theory I

2 Collective Consumption and Urban Contradictions in Advanced Capitalism

3 Urban Crisis, State Policies and the Crisis of the State: the French Experience

4 The Social Function of Urban Planning: State Action in the Urban-Industrial Development of the French Northern Coastline

5 Urban Renewal and Social Conflict

6 The Social Prerequisites for the Upheaval of Urban Social Movements: an Exploratory Study of the Paris Metropolitan Area, 1968-73

7 Ideological Mystification and Social Issues: the Ecological Action Movement in the United States

8 City, Class and Power

152

167

9 Conclusion: the New Frontiers of Urban Research I 74

$\begin{array}{ll}\text { Notes and References } & \text { I } 83\end{array}$

$\begin{array}{ll}\text { Index } & 193\end{array}$ 


\section{Acknowledgements}

The texts collected here have been produced and sometimes published elsewhere. 'Collective Consumption and Urban Contradictions in Advanced Capitalism' (written in 1973) was prepared for the International Seminar of the Council for European Studies' held at Monterosso (Italy) in November 1973. 'Urban Crisis, State Policies and the Crisis of the State: the French Experience' (written in 1976) was a contribution to a collective work on the state edited by N. Poulantzas, La crise de l'Etat (Paris: P.U.F., 1976). 'The Social Function of Urban Planning: State Action in the Urban-Industrial Development of the French Northern Coastline' (written in 1974) was part of a larger research project carried out in $197 \mathrm{I}-3$ on the intervention of the state in the industrial and urban planning of Dunkirk. It was published by Recherches sociologiques, Louvain, November 1975. 'Urban Renewal and Social Conflict' (written in 1971) was based on a study carried out in I 970 of Urban renewal in Paris, and was published by Social Sciences Information, 1972. 'The Social Prerequisites for the Upheaval of Urban Social Movements: an Explanatory Study of the Paris Metropolitan Area, 1968-73' (written in 1975) was based on collective research carried out in 1972-4 on urban social movements in the Paris region. It was published by the International fournal of Urban and Regional Research in 1977. 'Ideological Mystification and Social Issues: the Ecological Action Movement in the United States, (written in 1971) was a report for the International Symposium on the Environment, organised by the Museum of Modern Art of New York in January 1972. 'City, Class and Power' (written in 1976) is an essay synthesising the whole of our problematic, and was published by Le Monde Diplomatique in June 1976. We would like to give grateful thanks to those institutions and 
viii

journals who made possible the production of the articles collected here.

The author and publishers are also particularly grateful to Elizabeth Lebas for her work in translating many parts of the book and for her discerning comments on previously translated parts. 